\title{
Awareness, Frequency and prevalence of DKA with D.M. type 1 children in Al-Jouf Region
}

\author{
Atallah Fadel Alruwaili, Faisal Mohammed AlArjan, Abdulaziz Sayah Khafur Alruwaili, \\ Khalid sa'adi faleh alharbi, Faisal Abdulaziz Almulhim, Ali Hamoud Alenazi, Rayan Riyadh \\ Abdullah Aldandani, Ahmed Muteb Alhumidi Alanzi, Fawaz Rawi Alfuhigi, Ahmed Obaid \\ Aladham Alanazi \\ Pediatric Department, Al-jouf University \\ Corresponding author: Atallah Fadel Alruwaili Tel: +966 54486 5509, E-mail: GLX-7077@hotmail.com
}

\begin{abstract}
:
Background: Diabetes Mellitus (DM) is a developing worldwide wellbeing concern. In 2000, diabetes affected an expected 171 million individual's world-wide; moreover, by 2011 this had expanded to more than 366 million and numbers are relied upon to surpass 552 million by 2030. Objective: The present study aimed at increasing the awareness and prevents the complications of diabetes mellites type 1 in children. Methodology: The current study was a cross-sectional community-based study of a qualitative and quantitative approach. Our study enrolled 80 candidates, from both gender. Participants were subjected to controlled self-administered close-ended study questionnaire all through the period between July to August 2018; and one month for data analysis. Our current data were taken from Aljouf population in Saudi Arabia. Results: $(58 ; 72.5 \%)$ of the participants were having children with diabetes; where only 22; (27\%) of them were not having children with diabetes. Moreover, $60 ; 75 \%$ were answered that they have only one child with diabetes, while $(14 ; 17.5 \%)$ answered that they have two children and the lowest rate was for the third group who answered that they have more than three children $(6 ; 7.5 \%)$. Furthermore, the age ranges of the diabetic children were (1-5 years old) with proportions of $(14 ; 17.5 \%),(6-10$ years old) with $(28 ; 35 \%)$, and the highest range was (11+ years old) with $(38 ; 47.5 \%)$. Conclusion and Recommendation: the current study sheds light on a global and nationwide health problem that affects children in the first stage of life which is diabetes type 1 . It has a high rate in urban communities. The findings of the present study highlighted the need of raising and improving the awareness through educational programs about management of self-care to prevent and/or reduce the increasing numbers of children patients with DM1.
\end{abstract}

Keywords: diabetes, Mellitus, population, individual

\section{Introduction :}

Diabetes Mellitus (DM) is a developing worldwide wellbeing concern. In 2000, diabetes affected an expected 171 million individuals world-wide; moreover, by 2011 this had expanded to in excess of 366 million and numbers are relied upon to surpass 552 million by $2030^{(1)}$.

DM is a metabolic disease of numerous etiologies', portrayed by hyperglycemia coming about because of imperfections in insulin emission, insulin activity or in cooperation, and related with aggravation of sugar, fat and metabolism ${ }^{(2)}$. Furthermore, the three wellknown forms of diabetes are Type 1 Diabetes Mellitus (T1DM), Type 2 Diabetes Mellitus (T2DM) and Gestational Diabetes Mellitus $(\mathrm{GDM})^{(3)}$.

The most noteworthy pervasiveness of diabetes generally is estimated to happen in the Middle East and North Africa because of quick financial advancement, development and deviations in way of life designs in the local ${ }^{(1)}$. The Kingdom of Saudi Arabia (KSA) is not excepted from this international prevalent ${ }^{(4)}$, consequently, diabetes is the furthermost challenging health problem fronting the kingdom ${ }^{(5)}$.

A report by the Saudi Arabian Ministry of Health, indicated that around 0.9 million individuals were determined to have diabetes in 1992, however this figure increased to 2.5 million individuals in 2010, on behalf of a 2.7 time increment in the occurrence rates in under two decades. Furthermore, in 2015, 4660 patients with diabetes went to the family and therapeutic facilities crosswise over Saudi Arabia ${ }^{(6)}$. This expanding number of diabetes is because of different variables, including a rising stoutness rate and a maturing populace ${ }^{(7)}$. Moreover, patients with diabetes usually encounter other related chronic conditions, bringing about serious problems ${ }^{(3)}$. 
In spite of the advancement, in treatment and diagnosis of sort 1 diabetes, diabetic ketoacidosis (DKA) is as yet a serious clinical issue. The point of the examination was excessively depicted the study of disease transmission and clinical normal for DKA in children and teenagers with type 1 diabetes ${ }^{(8)}$. Diabetic ketoacidosis (DKA) is yet the most unsafe intense intricacy of sort 1 diabetes mellitus (T1DM). It is a death-defying condition requiring escalated treatment. DKA might be the primary side effect of already undiscovered diabetes, particularly in children (9).

\section{Objective:}

The present study aimed at increasing and improving the awareness and prevents the complications of diabetes mellites types 1 in children.

\section{Materials and Methods:}

The current study was a cross-sectional community-based study of a qualitative and quantitative approach. Our study enrolled 80 candidates, from both gender. Participants were subjected to controlled self-administered closeended study questionnaire all through the period between July to August 2018; and one month for data analysis. Our current data were taken from Al-jouf population in Saudi Arabia. Furthermore, study questionnaire was a health questionnaire convers 9 items that measuring the awareness and how to prevent the complications of diabetes mellites types 1 in children.

Items analysis was completed by means of proportion of answers and calculation of the mean.

Statistical data analysis procedure: All the results were analysed by using PSPP version 23.

\section{Results:}

$(58 ; 72.5 \%)$ of the participants were having children with diabetes; where only 22;27\%) of them were not having children with diabetes. Moreover, $(60 ; 75 \%)$ were answered that they have only one child with diabetes, $(14 ; 17.5 \%)$ two children and the lowest rate was for the third group answered that they have more than three children $(6 ; 7.5 \%)$. Furthermore, the age ranges of the diabetic children were (1-5 years old) with proportions of $(14 ; 17.5 \%),(6-10$ years old) with $(28 ; 35 \%)$, and the highest range was $(11+$ years old $)$ with $(38 ; 47.5 \%)$.

Moving to their knowledge about the causes of diabetes for children, $(52 ; 65 \%)$ answered with No whilst only $(28 ; 35 \%)$ with Yes. Besides, they were asked about their knowledge about the serious complications of diabetes in diabetic child, (No 46; 57.5\%) and (Yes 34; 42.5\%). Also, they responded with (No; 28-35\%) and (Yes; 52; 65\%) that their children experienced complications such as acidity due to high sugar or sharp drop in sugar levels. When they asked about their visit to hospital emergencies due to diabetes complications resulted from high or low sugar, the answers were as following (Once $30 ; 37.5 \%$ ), (Tree or more $38 ; 47.5 \%$ ) and (Twice 12; 15\%). Participants answered with (No 44; 55\%) and (Yes 36-45\%). The last question was about the best way is to deal with diabetes complications, the responses were (No 56; 70\%) and (Yes 24; 30\%).

\section{Discussion:}

Locally, diabetes is identified to be one of the most challenging health problems in Saudi Arabia ${ }^{(5)}$. Consequently, this fact brings us to a significant point of our study which is increasing the awareness and preventing the complications of diabetes mellites types 1 in children.

The current study indicated that $72.5 \%$ of the participants were having children with diabetes T1 DM, most likely other study conducted in Dhahran, Eastern KSA between 1990-2007. The results also showed an obvious increase to be double in neither children nor adults in less than two decades ${ }^{(10)}$. Our data revealed that the highest range was (11+ years old) with $47.5 \%$; moreover, in Al-Madina, children aged 5-9 and 10-12 years old had 1.8 and 2.7 times more risk of increasing T1DM in comparison with other children group aged $0-4$ years ${ }^{(11)}$. In addition, two studies were carried out in Riyadh and Jeddah and indicated that the prevalence rates of diabetes were higher in females compared to men group in younger ages between 7 to 17 and 12-19 correspondingly ${ }^{(12,13)}$. Urban communities are documented to have the high rate of T1DM cases with proportions of $77.2 \%$ compared to rural communities ${ }^{(14)}$.

\section{Table 1: keys measure for the awareness of parents about children with diabetes.}




\begin{tabular}{|c|c|c|c|c|c|}
\hline & Value & Frequency & Percent & $\begin{array}{l}\text { Valid } \\
\text { Percent }\end{array}$ & $\begin{array}{l}\text { Cum } \\
\text { Percent }\end{array}$ \\
\hline Do you have a child with diabetes? & $\begin{array}{l}\text { No } \\
\text { Yes } \\
\text { Total }\end{array}$ & $\begin{array}{l}22 \\
58 \\
80\end{array}$ & $\begin{array}{l}27.50 \\
72.50 \\
100\end{array}$ & $\begin{array}{l}27.50 \\
72.50 \\
100\end{array}$ & $\begin{array}{l}27.50 \\
100\end{array}$ \\
\hline $\begin{array}{l}\text { How many children do you have with } \\
\text { diabetes? }\end{array}$ & $\begin{array}{l}\text { One } \\
\text { Two } \\
\text { Three or more } \\
\text { Total }\end{array}$ & $\begin{array}{l}60 \\
14 \\
6 \\
80\end{array}$ & $\begin{array}{l}75 \\
17.50 \\
7.50 \\
100\end{array}$ & $\begin{array}{l}75 \\
17.50 \\
7.50 \\
100\end{array}$ & $\begin{array}{l}75 \\
92.50 \\
100\end{array}$ \\
\hline How old is the diabetic child? & $\begin{array}{l}(1-5) \\
(6-10) \\
11+ \\
\text { Total } \\
\end{array}$ & $\begin{array}{l}14 \\
28 \\
38 \\
80\end{array}$ & $\begin{array}{l}17.50 \\
35 \\
47.50 \\
100\end{array}$ & $\begin{array}{l}17.50 \\
35 \\
47.50 \\
100\end{array}$ & $\begin{array}{l}17.50 \\
52.50 \\
100\end{array}$ \\
\hline $\begin{array}{l}\text { Do you know the causes of diabetes } \\
\text { for children? }\end{array}$ & $\begin{array}{l}\text { No } \\
\text { Yes } \\
\text { Total } \\
\end{array}$ & $\begin{array}{l}52 \\
28 \\
80 \\
\end{array}$ & $\begin{array}{l}65 \\
35 \\
100 \\
\end{array}$ & $\begin{array}{l}65 \\
35 \\
100 \\
\end{array}$ & $\begin{array}{l}65 \\
100\end{array}$ \\
\hline $\begin{array}{l}\text { Do you know the serious } \\
\text { complications of diabetes in diabetic } \\
\text { child? }\end{array}$ & $\begin{array}{l}\text { No } \\
\text { Yes } \\
\text { Total } \\
\end{array}$ & $\begin{array}{l}46 \\
34 \\
80 \\
\end{array}$ & $\begin{array}{l}57.50 \\
42.50 \\
100 \\
\end{array}$ & $\begin{array}{l}57.50 \\
42.50 \\
100 \\
\end{array}$ & $\begin{array}{l}57.50 \\
100\end{array}$ \\
\hline $\begin{array}{l}\text { Does your child experience } \\
\text { complications such as acidity due to } \\
\text { high sugar or sharp drop in sugar } \\
\text { levels? }\end{array}$ & $\begin{array}{l}\text { No } \\
\text { Yes } \\
\text { Total }\end{array}$ & $\begin{array}{l}28 \\
52 \\
80\end{array}$ & $\begin{array}{l}35 \\
65 \\
100\end{array}$ & $\begin{array}{l}35 \\
65 \\
100\end{array}$ & $\begin{array}{l}35 \\
100\end{array}$ \\
\hline $\begin{array}{l}\text { How often have you visited hospital } \\
\text { emergencies due to diabetes } \\
\text { complications resulted from high or } \\
\text { low sugar? }\end{array}$ & $\begin{array}{l}\text { Once } \\
\text { Three or more } \\
\text { Twice } \\
\text { Total }\end{array}$ & $\begin{array}{l}30 \\
38 \\
12 \\
80\end{array}$ & $\begin{array}{l}37.50 \\
47.50 \\
15 \\
100\end{array}$ & $\begin{array}{l}37.50 \\
47.50 \\
15 \\
100\end{array}$ & $\begin{array}{l}37.50 \\
85 \\
100\end{array}$ \\
\hline Do you know what causes diabetes? & $\begin{array}{l}\text { No } \\
\text { Yes } \\
\text { Total } \\
\end{array}$ & $\begin{array}{l}44 \\
36 \\
80 \\
\end{array}$ & $\begin{array}{l}55 \\
45 \\
100 \\
\end{array}$ & $\begin{array}{l}55 \\
45 \\
100 \\
\end{array}$ & $\begin{array}{l}55 \\
100\end{array}$ \\
\hline $\begin{array}{l}\text { Do you know what the best way is to } \\
\text { deal with diabetes complications? }\end{array}$ & $\begin{array}{l}\text { No } \\
\text { Yes } \\
\text { Total }\end{array}$ & $\begin{array}{l}56 \\
24 \\
80 \\
\end{array}$ & $\begin{array}{l}70 \\
30 \\
100 \\
\end{array}$ & $\begin{array}{l}70 \\
30 \\
100 \\
\end{array}$ & $\begin{array}{l}70 \\
100\end{array}$ \\
\hline
\end{tabular}

The fourth question was estimating their insight about the causes of diabetes in childern. (65\%) replied with No while just (35\%) with Yes, even the serious complications with percentage of $57.5 \%$. These results demonstrate the lack of knowledge and awareness of the parents about the disease. Therfore, $65 \%$ children have experienced complications such as acidity due to high sugar or sharp drop in sugar levels as it shows in our results. Frequently, visited hospital emergencies due to diabetes complications resulted from high or low sugar had increase to be more than three times $47.5 \%$ since $60 \%$ doesn't know how to deal with diabetes complications.

The most recent report issued by the International Diabetes Federation refered to 16,100 children aged 0-14 living with T1DM in Saudi Arabia ; with an occurrence of 31.4 new cases for each 100,000 individually ${ }^{(1)}$. The International Diabetes Federation revealed that the high occurrence rate of diabetes ought not out of the ordinary among females instead of males by $2030^{(1)}$. The purpose behind this is unverfiable; gender varities are regularly related condition and culture, while hereditary elements are for the most part expected to assume a noteworthy to be the main role for the increment of T1DM ${ }^{(15)}$. Diabetes has been also linked with development of obesity and overweight in early stage of adulthood ${ }^{(16)}$.

\section{Conclusion and Recommendation:}

In short, the current study sheds light on the danger of DM1 as a global and nationwide health problem that affects children in the first stage of life. It has a high rate in urban communities. Moreover, obesity plays a significant role in developing diabetes besides socio-economic and geographical factors ${ }^{(17)}$. The findings of the present study concentrated on the need of raising and improving awareness through educational programs about management of self-care in avoiding and decreasing the percentage of occurrence of the disease.

\section{References:}

1- International Diabetes Federation (2015): IDF Diabetes Atlas (7th ed). 
http://www.idf.org/sites/default/files/E N_6E_Atlas_Full_0.pdf.

2- American Diabetes Association (2010): Diagnosis and classification of diabetes mellitus. Diabetes Care, 33(1): S62-9.

3- International Diabetes Federation (2014): IDF Diabetes Atlas (6th ed). http://www.idf.org/sites/default/files/E N_6E_Atlas_Full_0.pdf.

4- Alhowaish AK (2013): Economic costs of diabetes in Saudi Arabia. J Family Commun Med., https://www.ncbi.nlm.nih.gov/pmc/arti cles/PMC3663158/

5- Tabish SA (2007): Is diabetes becoming the biggest epidemic of the twenty-first century? Int J Health Sci., https://www.ncbi.nlm.nih.gov/pmc/arti cles/PMC3068646/

6- The Ministry of Health (2015): Statistics report. http://www.moh.gov.sa/en/Ministry/St atistics/book/Pages/default.aspx.

7- Kearns K, Dee A, Fitzgerald AP, Doherty E, and Perry IJ (2014): Chronic disease burden associated with overweight and obesity in Ireland: the effects of a small BMI reduction at population level. BMC Public Health, https://www.ncbi.nlm.nih.gov/pubmed 124512151

8- Pietrzak I, Mianowska B, Zmysłowska A, Fendler $\underline{W}$, Młynarski W, and Szadkowska A (2016): Epidemiology and clinical course of diabetic ketoacidosis in children and adolescents with type 1 diabetes mellitus. https://www.ncbi.nlm.nih.gov/pmc/arti cles/PMC4691462/

9- Chumiecki M, Prokopowicz Z, Deja $\underline{\mathbf{R}}$ and Jarosz-Chobot $P$ (2013): Frequency and clinical manifestation of diabetic ketoacidosis in children with newly diagnosed type 1 diabetes. https://www.ncbi.nlm.nih.gov/pubmed 125612814

10- Abduljabbar MA, Aljubeh JM, Amalraj A, and Cherian MP (2010):
Incidence Trends of Childhood Type 1 Diabetes in eastern Saudi Arabia. Saudi Med J., 31 (4):413-8.

11- Habeb AM, Al-Magamsi MS, Halabi S, Eid IM, Shalaby S, and Bakoush O (2011): High incidence of Childhood Type 1 Diabetes in Al-Madina, North West Saudi Arabia (2004-2009). Pediatr Diab., 12 (8): 676-81

12- Al-Daghri NM, Al-Attas OS, Alokail MS, Alkharfy KM, Yousef M, Sabico SL et al. (2011): Diabetes Mellitus Type 2 and other chronic non-communicable diseases in the central region Saudi Arabia (Riyadh cohort 2): a decade of an epidemic. BMC Med.,

https://www.ncbi.nlm.nih.gov/pubmed/21 689399

13- Alqurashi KA, Aljabri KS, and Bokhari SA (2011): Prevalence of Diabetes Mellitus in a Saudi Community. Ann Saudi Med., https://www.ncbi.nlm.nih.gov/pmc/articles /PMC4633187/

14- Alrubeaan K (2015): National Surveillance of Type 1, Type 2 Diabetes and prediabetes among children and adolescents: a population-based study (Saudi-DM). J Epidemiol Commun Health, 69(11):1045-51.

15- Dean L and McEntyre J (2004): The genetic Landscape of Diabetes. NCBI., https://www.ncbi.nlm.nih.gov/books/NBK $\underline{1667 /}$

16- Szadkowska A, Madej A, Ziółkowska $\mathrm{K}$, Szymańska M,Jeziorny $\mathrm{K}$ et al. (2015): Gender and Age - Dependent effect of type 1 diabetes on obesity and altered body composition in young adults. http://agro.icm.edu.pl/agro/element/bwmet a1.element.agro-80c22a03-3254-4431a656-17d1ae77cbd6/c/1.pdf

17- Alotaibi A, Perry L, Ghoizadeh L and AlGanmi A (2017): Incidence and Prevalence rates of Diabetes Mellitus in Saudi Arabia: an overview. https://www.ncbi.nlm.nih.gov/pubmed/29 $\underline{110860}$ 